\title{
The metabolic effects of drugs used for the treatment of polycystic ovary syndrome
}

Polikistik over sendromu tedavisinde kullanilan ilaçların metabolik etkileri

\author{
Melia Karaköse ${ }^{1}$, Erman Çakal ${ }^{1}$, Kubilay Ertan², Tuncay Delibaşı ${ }^{1}$ \\ 'Department of Endocrinology and Metabolism, Dişkapı Ylldırm Beyazıt Training and Research Hospital, Ankara, Turkey \\ ${ }^{2}$ Department of Obstetrics and Gynecology, Hospital of Leverkusen, Teaching Hospital of University of Cologne, \\ Leverkusen, Germany
}

\section{Abstract}

Polycystic ovary syndrome (PCOS) is the most common endocrine disorder among women of reproductive age. It is characterized by menstrual disorders, hyperandrogenism (clinical and/or biochemical) and ultrasonographic features. It is well known that PCOS has unfavourable effects on carbohydrate metabolism, the parameters of cardiovascular disease and lipid profile. Mode of treatment is mainly guided by the main complaint of the patient. A lot of medicines have been used for many years to treat these women. For that reason the recognition the effects of these drugs on the metabolic risk profile is important. The aim of this review was to evaluate the effects of these drugs on metabolic parameters in women with PCOS.

(J Turkish-German Gynecol Assoc 2013; 14: 168-73)

Key words: Polycystic ovary syndrome, treatment, drug effects; metabolic parameter

Received: 13 June, 2013

Accepted: 30 June, 2013

\section{Ozet}

Polikistik over sendromu (PKOS), üreme çağındaki kadınlarda en sık görülen endokrin bozukluktur. Menstruel bozukluklar, hiperandrojenizm (klinik ve/veya biyokimyasal) ve ultrasonografik özellikleriyle karakterizedir. PKOS'nun karbonhidrat metabolizması, kardiyovasküler hastalık parametreleri ve lipid profili üzerine olan olumsuz etkileri iyi bilinmektedir. Tedavi şekli genelde hastanın asıl yakınmasına göre düzenlenir. Bu kadınların tedavisinde uzun yıllardan beri çeşitli ilaçlar kullanılmaktadır. Bu nedenle de tedavide kullanılan bu ilaçların, metabolik risk profili üzerine olan etkilerini bilmek önemli hale gelmektedir. Bu derlemenin amacı tedavide kullanılan bu ilaçların, PKOS'lu bayanların metabolik parametreleri üzerine olan etkilerini değerlendirmektir. (J Turkish-German Gynecol Assoc 2013; 14: 168-73)

Anahtar kelimeler: Polikistik over sendromu, tedavi, ilaç etkileri, metabolik parametre

Geliş Tarihi: 13 Haziran 2013

Kabul Tarihi: 30 Haziran 2013

\section{Introduction}

Polycystic ovary syndrome (PCOS) is the most common endocrine disorder among women of reproductive age, and is characterized by anovulation, hyperandrogenemia, obesity and insulin resistance (1-3).

PCOS was defined by Stein and Leventhal for the first time in 1935 as hyperandrogenemia, menstrual irregularity, large polycystic ovaries and obesity (4). The Rotterdam criteria, which we currently use frequently in PCOS diagnosis, were defined in 2003 (5). These criteria include; polycystic ovaries seen by ultrasound; $\geq 12$ follicles in each ovary with a diameter of 2-9 $\mathrm{mm}$ and/or increase in the ovarian volume $\left(>10 \mathrm{~cm}^{3}\right)$, chronic oligo-anovulation and hyperandrogenemia (determined clinically or in the laboratory). Other diseases should be excluded and at least two of these three criteria should be present to make a diagnosis. The PCOS criteria were rearranged by the Androgen Excess Society in 2009; these include androgen excess (clinical and/or biochemical hyperandrogenism), ovarian dysfunction (oligo-anovulation and/or polycystic ovarian morphology) and exclusion of other diseases with hyperandrogenism and exclusion of ovulatory diseases (6). The Androgen Excess Society recommends that all three criteria should be present for a diagnosis of PCOS.

The prevalence of the syndrome has been reported to be approximately 6-8\% (7). The ultrasonographic prevalence of PCOS ranges between $14 \%$ and $23 \%(8,9)$. There are no differences in PCOS prevalence in terms of ethnic background (10). The etiology of PCOS is not exactly known. Genetic and environmental factors have been blamed. The frequencies of hyperandrogenism and menstrual dysfunction are increased in the mothers and sisters of patients with PCOS. Serum androgen levels are increased in the fathers and brothers of patients with PCOS (11). Different studies in which potential genetic defects which might be involved in development of PCOS were examined showed that the syndrome is a complex polygenic defect (12). No specific environmental factors have been defined, but obesity is especially emphasized. The frequency of obesity in PCOS has been reported to be $40-60 \%$ (13). Obesity increases the prevalence of PCOS (14).

Three theories are emphasized in its pathophysiology. These include hypothalamic-pituitary dysfunction, ovarian hyper- 
androgenism and peripheral insulin resistance. Intraovarian androgen excess is responsible of both anovulation and the development of numerous follicle cysts. According to the abnormal pituitary function hypothesis, the increase in the frequency and amplitude of pulsatile secretion of LH increases androgen production in the ovaries. This results in discontinued follicle development (15). In addition, increased androgen blocks the inhibitory action of progesterone on the hypophysis. According to the hypothesis of ovarian hyperandrogenism, mainly primary functional ovarian hyperandrogenism is involved in PCOS (16). In vitro studies have shown an abnormal steroidogenic phenotype in isolated theca cell culture (17). According to the third hypothesis, insulin resistance and hyperinsulinemia are important factors in steroidogenic dysfunction in PCOS $(18,19)$. Insulin resistance and hyperinsulinemia stimulate androgen synthesis in the ovaries and lead to an increase in the levels of free testosterone by decreasing the synthesis of sex hormone binding globulin (SHBG) in the liver. Insulin resistance also contributes to the development of metabolic syndrome. Metabolic syndrome is present in $25 \%$ of adolescent PCOS cases and in $40 \%$ of adults aged 40 years with PCOS (20-23). One third of PCOS patients have an abnormal glucose tolerance test and $10 \%$ have type 2 diabetes mellitus (24).

PCOS generally presents with menstrual irregularity (oligoamenorrhea, dysfunctional uterine bleeding), hyperandrogenism findings (hirsutism, acne, oily skin, androgenic alopecia), infertility and obesity. Other clinical conditions related to PCOS include impaired glucose tolerance (IGT), type 2 diabetes mellitus (24), metabolic syndrome (20-23), non-alcoholic steatohepatitis (14), sleep apnea syndrome (25), malignancy (endometrium, ovary, breast cancer) $(14,26)$ and increased cardiovascular risk (27-29). An atherogenic lipid profile is observed as a result of increased LDL cholesterol, increased triglyceride levels and decreased HDL cholesterol levels in these patients (30-32).

Since the etiopathogenesis of PCOS is not clearly known, current treatment options are generally symptomatic. Two categories are emphasized in treatment. These include treatment of anovulatory infertility and treatment of the symptoms related to PCOS (menstrual dysfunction, hirsutism, infertility, etc.). The first step in the treatment of the symptoms related to PCOS includes lifestyle changes and weight loss, if the patient is obese. Medical treatment includes combined oral contraceptives (COC), spironolactone, finasteride, flutamide, metformin and combinations of these treatments.

COCs contain a progestin and ethinyl estradiol, which is a synthetic estrogen. Many of these progestins (levonorgestrel, norgestrel, desogestrel, gestodene, noretindrone) are derivatives of testosterone and show androgenic properties (33). Drospienone and cyproterone acetate (CPA), which are among the other progestins, are not structurally related to testosterone and show antiandrogenic activity. CPA blocks androgen receptors and inhibits 5- $\alpha$-reductase activity (34). Thus, the serum androgen level is decreased. Drospirenone decreases blood pressure with its anti-mineralocorticoid action in addition to its anti-androgenic property. Conclusively, CPA and COCs which contain drospirenone suppress ovarian androgen production by inhibiting LH secretion, decrease serum free testosterone levels by increasing the synthesis of SHBG in the liver, block androgen receptors and thus regular menstruation, and prevent endometrial hyperplasia such that a decrease in the risk of endometrial cancer and regression of hirsutism are observed.

Spironolactone is an aldosterone antagonist, and its action is dependent on the dose. It is a competitive inhibitor of androgen receptors and also inhibits the activity of 5 - $\alpha$-reductase. Finasteride inhibits the activity of $5 \alpha$-reductase and is less effective compared to the other anti-androgens (35). Flutamide is an androgen receptor blocker. Its efficiency is similar to spironolactone (36)

Metformin decreases ovarian androgen production by decreasing the serum insulin level and mitigating insulin resistance (37). Thus, the serum testosterone level decreases, the hirsutism score and menstrual dysfunction improve and infertility is reversed (38).

The negative effects of PCOS on carbohydrate metabolism, cardiovascular disease parameters and the lipid profile are wellknown. Therefore, it becomes important to know the effects of the drugs used commonly in PCOS treatment on the metabolic risk profile.

\section{Metabolic effects of drugs}

COCs have been used in the treatment of PCOS for more than 30 years. There are various studies evaluating the effects of COCs on carbohydrate metabolism, the lipid profile and cardiovascular risk parameters.

Morin-Papunen et al. (39) compared the metabolic and endocrine effects of metformin and an oral contraceptive tablet (Diane 35) containing ethinyl estradiol (35 $\mu \mathrm{g}$ ) and cyproterone acetate (CPA) (2 mg) in obese women with PCOS. Eighteen patients with a body mass index (BMI) above 27 were included in the study. Eight patients were given metformin and ten patients were given an oral contraceptive tablet for 6 months; the effects were evaluated at the beginning and at the end of the treatment period. The waist/hip ratio, as well as the serum free fatty acid, fasting insulin and fasting blood glucose levels decreased significantly in the group who received metformin $(\mathrm{p}<0.05)$, and impaired fasting glucose (IFG) returned to normal in one patient. The menstrual cycle improved, but the hirsutism score did not change in these patients. In the group who received Diane 35, the waist/hip ratio, serum free fatty acids, fasting insulin and fasting blood glucose did not change. One patient showed progression from IFG to diabetes mellitus and IGT developed in three patients. The menstrual cycle improved and hirsutism score decreased in the patients given Diane 35.

Mastorakos et al. (40) compared the effects of two different COCs on androgen and lipid parameters in patients with PCOS; $30 \mu \mathrm{g}$ ethinyl estradiol $+0.15 \mathrm{mg}$ desogestrel were given to group $A(n=14)$ and $35 \mu$ g ethinyl estradiol +2 mg cyproterone acetate were given to group B $(n=14)$ for 12 months and the findings were compared at the beginning and at the end of the treatment period. In both groups, total and free testosterone levels decreased, the hirsutism score was reduced, total cholesterol (TC), LDL and HDL increased, the TC/HDL and LDL/HDL ratios did not change and a significant increase was found in TG levels in group B compared to group A. 
In another study performed by Mastorakos et al. (41), the effects of two different COCs on carbohydrate metabolism were evaluated; $30 \mu$ g ethinyl estradiol $+0.15 \mathrm{mg}$ desogestrel were given to group $\mathrm{A}(\mathrm{n}=18)$ and $35 \mu \mathrm{g}$ ethinyl estradiol + $2 \mathrm{mg}$ cyproterone acetate were given to group B $(n=18)$ for 12 months and the findings were compared at the beginning and at the end of the treatment period. In both groups, insulin resistance increased. The fasting blood glucose/insulin ratio decreased and first and second phase insulin secretion in OGTT was increased in group B. Conclusively, oral contraceptive drugs led to a change in insulin sensitivity. In addition, cyproterone acetate was related to an increase in insulin secretion and hyperinsulinemia.

Orbetsova et al. (42) evaluated anti-androgens and the effects of combinations of anti-androgens and insulin sensitizing agents on metabolic and hormonal parameters in women with PCOS. Forty-four patients were included in the study and divided into three groups. Diane 35 was given to the first group, Diane $35+$ metformin were given to the second group and Diane $35+$ rosiglitazone were given to the third group for 6 months. The body weight, body fat mass and abdominal fat distribution did not change in the first group. Despite mild hyperinsulinemic action, no change was found in carbohydrate tolerance. Negative effects were observed on atherogenic lipids. In the second group, the body fat mass and abdominal fat distribution decreased, blood glucose levels did not change, insulin levels decreased, diastolic blood pressure decreased and a positive effect was observed on HDL, while a neutral effect was observed on atherogenic lipids. In the third group, the body fat mass and abdominal fat distribution did not change, fasting blood glucose did not change, fasting insulin levels and the Homeostasis Model of Assessment-Insulin Resistance (HOMA-IR) decreased and a neutral effect was observed on atherogenic lipids.

In a meta-analysis comparing the efficiency of placebo with thiazolidinediones in PCOS (43), it was shown that thiazolidinediones decreased insulin and fasting blood glucose levels, but were not efficient in decreasing the Ferriman-Gallwey score and androgen levels and led to weight gain.

Gode et al. (44) evaluated the effects of ethinyl estradiol + cyproterone acetate on cardiovascular risk parameters. 40 patients were given a COC containing cyproterone acetate for 6 months. At the end of the treatment period, TC, LDL and TG increased compared to the baseline values $(\mathrm{p}<0.05)$. A significant increase was found in the carotid intima-media thickness $(0.03 \pm 0.01 \mathrm{~mm})(\mathrm{p}<0.05)$. Brachial artery flow-mediated dilatation was observed to be decreased $(p<0.05)$.

In a study in which the effects of medical treatment on endothelial function and insulin resistance were evaluated in patients with PCOS (45), one group was given metformin $(n=36)$ and the other group $(n=30)$ was given $35 \mu \mathrm{g}$ ethinyl estradiol $+2 \mathrm{mg}$ cyproterone acetate for 6 months. The effects were compared at the beginning and at the end of the treatment period. Glucose and insulin levels were evaluated using the oral glucose tolerance test. In the group who received metformin, the insulin, high sensitivity C-reactive protein (HS-CRP) and HDL levels decreased and brachial artery flow-mediated dilatation increased. In the group who received $\mathrm{COC}$, the insulin, $\mathrm{HS}-\mathrm{CRP}$, glucose, SHBG and TG levels increased, while plasminogen activator inhibitor-1, LDL and testosterone levels decreased.

Ozkaya et al. (46) gave metformin twice a day to 19 women with PCOS for 3 months. The effects were evaluated at the beginning and at the end of the treatment period. Fasting insulin, free testosterone, dehydroepiandrosterone sulfate and visfatin levels decreased. HOMA-IR, BMI and waist circumference values also decreased. The changes in TC, HDL, LDL, TG and prolactin concentrations were not significant.

Kriplani et al. (47) investigated the effects of two different COCs on clinical and biochemical parameters in patients with PCOS. Group A was given $(n=30) 30 \mu$ g ethinyl estradiol $+3 \mathrm{mg}$ drospirenone and group B was given $(n=30) 30 \mu \mathrm{g}$ ethinyl estradiol $+0.15 \mathrm{mg}$ desogestrel for 6 months and the effects were compared at the beginning and at the end of the treatment period. In group A, LDL decreased, HDL increased, fasting blood glucose, postprandial blood glucose and insulin level decreased, the hirsutism score improved and systolic-diastolic blood pressure decreased. In group B, fasting blood glucose, postprandial blood glucose and insulin level increased, the hirsutism score did not change, and systolic and diastolic blood pressure increased. Conclusively, it was interpreted that drospirenone was more efficient compared to the COC containing desogestrel because of its positive antiandrogenic effects on menstrual cycle regularity, blood pressure and lipid profile.

In a different study (48), $30 \mu \mathrm{g}$ ethinyl estradiol $+3 \mathrm{mg}$ drospirenone were given to 20 women with PCOS for 6 months. When the effects were evaluated at the beginning and at the end of the treatment period, it was found that testosterone levels decreased, SHBG levels increased and the hirsutism score improved, while no significant effects were observed on carbohydrate metabolism (FBG, fasting insulin, HOMA IR).

In a study where the effect of COC on body composition was evaluated in patients with PCOS (49), $30 \mu \mathrm{g}$ ethinyl estradiol + $3 \mathrm{mg}$ drospirenone were given to patients for 6 months. After 6 months of treatment, no changes were observed in body weight, BMI and waist/hip ratio, while a significant increase was found in the total fat percentage and central fat percentage. While the lipid parameters were increased (TC, LDL, TG, HDL), no changes were observed in insulin resistance and glucose metabolism.

Nakhjavani et al. (50) gave $100 \mathrm{mg}$ spironolactone to 27 patients (20 PCOS + 7 idiopathic hirsutism) for 3 months and evaluated the lipid profile. Testosterone, dehydroepiandrosterone sulfate and prolactin levels decreased. TC, TG and FBG levels did not change. LDL, TC/HDL increased, while HDL decreased.

In a study which compared the efficiencies of spironolactone and metformin (51), group A $(n=34)$ was given $50 \mathrm{mg} /$ day spironolactone and group B $(n=35)$ was given $1000 \mathrm{mg} /$ day metformin for 6 months. In both groups, improvements were observed in the menstrual cycle, hirsutism score, glucose tolerance and HOMA-IR. The LH/FSH ratio and testosterone levels decreased. The blood pressure, BMI and waist/hip ratio did not 
Table 1. Metabolic effects of the drugs used to treat PCOS

\begin{tabular}{|l|c|c|c|c|c|}
\hline & $\begin{array}{c}\text { Carbohydrate } \\
\text { metabolism }\end{array}$ & $\begin{array}{c}\text { Lipid } \\
\text { profile }\end{array}$ & $\begin{array}{c}\text { Hormonal } \\
\text { profile }\end{array}$ & $\begin{array}{c}\text { Hirsutism } \\
\text { score }\end{array}$ & $\begin{array}{c}\text { Menstrual } \\
\text { dysfunction }\end{array}$ \\
\hline Metformin & positive & positive & positive or neutral & positive or neutral & positive \\
\hline Cyproterone acetate & negative & negative & positive & positive & positive \\
\hline Drospirenone & positive or neutral & positive & positive & positive & positive \\
\hline Desogestrel & negative & negative & positive or neutral & positive or neutral & positive \\
\hline Spironolactone & positive or neutral & negative & positive & positive & positive \\
\hline
\end{tabular}

change. Conclusively, it was interpreted that both drugs were efficient in the treatment of PCOS, but spironolactone was superior to metformin in the treatment of hirsutism, menstrual imbalance and hormonal imbalance with a slight increase in side effects.

In a meta-analysis which evaluated the efficiency of exercise treatment in PCOS (52), the results of eight studies which included moderate physical activity and exercise periods ranging between 12 and 24 weeks were assessed. A 4.5-10\% decrease in body weight, a 9-30\% improvement in insulin resistance and improved ovulatory functions were observed with exercise. This was found to be independent of the type of exercise and the frequency and time of the sessions.

In summary, these studies generally show that cyproterone acetate has favorable effects on menstrual dysfunction, hirsutism score and hormonal profile and unfavorable effects on the lipid profile, carbohydrate metabolism and cardiovascular risk parameters. Drospirenone has favorable effects on menstrual dysfunction, hirsutism score, hormonal profile, carbohydrate metabolism, lipid profile and blood pressure. Spironolactone has favorable or neutral effects on carbohydrate metabolism, favorable effects on hirsutism score and hormonal profile and unfavorable effects on the lipid profile. Metformin has favorable effects on carbohydrate metabolism, menstrual dysfunction, lipid profile and favorable or neutral effects on the hormonal profile and hirsutism score (Table 1).

\section{Conclusion}

PCOS is a metabolic disease which has unfavorable effects on the lipid profile, carbohydrate metabolism and cardiovascular risk parameters. It has been shown that some drugs which are used in treatment of PCOS also have unfavorable effects on these parameters. Therefore, the metabolic effects of the drugs should be considered in treatment selection.

\section{Ethics Committee Approval: N/A}

Informed Consent: $N / A$

Peer-review: Externally peer-reviewed.

Author contributions: Concept - M.K., T.D.; Design - M.K, T.D.; Supervision - K.E., T.D.; Resource - M.K., T.D.; Materials - M.K., E.Ç.; Data Collection\&/or Processing - M.K., E.Ç.; Analysis\&/or Interpretation - M.K.; Literature Search - M.K.; Writing - M.K.; Critical Reviews - K.E., T.D.
Conflict of Interest: No conflict of interest was declared by the authors.

Financial Disclosure: No financial disclosure was declared by the authors.

\section{References}

1. Diamanti-Kandarakis E, Kouli CR, Bergiele AT, Filandra FA, Tsianateli TC, Spina GG, et al. A survey of the polycystic ovary syndrome in the Greek island of Lesbos: hormonal and metabolic profile. J Clin Endocrinol Metab 1999; 84: 4006-11. [CrossRef]

2. Ehrmann DA, Bames RB, Rosenfild RL, Cavaghan MK, Imperial J. Prevalence of impaired glucose tolerance and diabetes in women with polycystic ovary syndrome. Diabetes Care 1999; 22: 141-6. [CrossRef]

3. Orio F Jr, Palomba S, Spinelli L, Cascella T, Tauchmanova L, Zullo $\mathrm{F}$, et al. The cardiovascular risk of young women with polycystic ovary syndrome: an observational, analytical, prospective case-control study. J Clin Endocrinol Metab 2004; 89; 3696-701. [CrossRef]

4. Stein IF, Leventhal NL. Amenorrhea associated with bilateral polycystic ovaries. Am J Obstet Gynecol 1935; 29: 181-91.

5. Rotterdam ESHRE/ASRM-Sponsored PCOS Consensus Workshop Group. Revised 2003 consensus on diagnostic criteria and longterm health risks related to polycystic ovary syndrome. Fertil Steril 2003; 81: 19-25.

6. Azziz R, Carmina E, Dewailly D, Diamanti-Kandarakis E, EscobarMorreale HF, Futterweit W, et al. The Androgen Excessand PCOS Society criteria for the polycystic ovary syndrome: the complete task force report. Fertil Steril 2009; 91: 456-88. [CrossRef]

7. Azziz R, Woods KS, Reyna R, Key TJ, Knochenhauer ES, Yildiz BO. The prevalence and features of the polycystic ovary syndrome in an unselected population. J Clin Endocrinol Metab 2004; 89: 2745-9. [CrossRef]

8. Farquhar CM, Birdsall M, Manning P, Mitchell JM, France JT. The prevalence of polycystic ovaries on ultrasound scanning in a population of randomly selected women. Aust NZ J Obstet Gynecol 1994; 34: 67-72.

9. Koivunen R, Laatikainen T, Tomas C, Huhtaniemi I, Tapanainen $\mathrm{J}$, Martikainen $\mathrm{H}$. The prevalence of polycystic ovaries in healthy women. Acta Obstet Gynecol Scand 1999; 78: 137-41. [CrossRef]

10. Knochenhauer ES, Key TJ, Kahsar-Miller M, Waggoner W, Boots LR, Azziz R. Prevalence of the polycystic ovary syndrome in unselected black and white women of the southeastern United States: a prospective study. J Clin Endocrinol Metab 1998; 83: 3078-82. [CrossRef]

11. Yildiz BO, Yarali H, Oguz H, Bayraktar M. Glucose intolerance, insulin resistance, and hyperandrogenemia in first degree relatives of women with polycystic ovary syndrome. J Clin Endocrinol Metab 2003; 88: 2031-6. [CrossRef] 
12. Crosignani PG, Nicolosi AE. Polycystic ovarian disease: heritability and heterogeneity. Hum Reprod Update 2001; 7: 3-7. [CrossRef]

13. Azziz R, Woods KS, Reyna R, Key TJ, Knochenhauer ES, Yildiz BO. The prevalence and features of the polycystic ovary syndrome in an unselected population. J Clin Endocrinol Metab 2004; 89: 2745-9. [CrossRef]

14. Legro RS. Evaluation and treatment of polycystic ovary syndrome. 2009/endotext.

15. Taylor AE, McCourt B, Martin KA, Anderson EJ, Adams JM, Schoenfeld D, et al. Determinants of abnormal gonadotropin secretion in clinically defined women with polycystic ovary syndrome. J Clin Endocrinol Metab 1997; 82: 2248-56. [CrossRef]

16. Rosenfield RL. Ovarian and adrenal function in polycystic ovary syndrome. Endocrinol Metab Clin North Am 1999; 28: 265-93. [CrossRef]

17. Nelson VL, Legro RS, Strauss JF 3rd, McAllister JM. Augmented and rogen production is a stable steroidogenic phenotype of propagated the ca cells from polycystic ovaries. Mol Endocrinol 1999; 13: 946-57. [CrossRef]

18. Rosenfield RL. Polycystic ovary syndrome and insulin-resistant hyperinsulinemia. J Am Acad Dermatol 2001; 45: S95. [CrossRef]

19. Ciaraldi TP, Aroda V, Mudaliar S, Chang RJ, Henry RR. Polycystic ovary syndrome is associated with tissue -specific differences in insulin resistance. J Clin Endocrinol Metab 2009; 94: 157-63. [CrossRef]

20. Coviello AD, Legro RS, Dunaif A. Adolescent girls with polycystic ovary syndrome have an increased risk of the metabolic syndrome associated with increasing and rogen levels independent of obesity and insulin resistance. J Clin Endocrinol Metab 2006; 91: 492-7. [CrossRef]

21. Leibel NI, Baumann EE, Kocherginsky M, Rosenfield RL. Relationship of adolescent polycystic ovary syndrome to parental metabolic syndrome. J Clin Endocrinol Metab 2006; 91: 1275-83. [CrossRef]

22. Rossi B, Sukalich S, Droz J, Griffin A, Cook S, Blumkin A, et al. Prevalence of metabolic syndrome and related characteristics in obese adolescents with and without polycystic ovary syndrome. J Clin Endocrinol Metab 2008; 93: 4780-6. [CrossRef]

23. Apridonidze T, Essah PA, Iuorno MJ, Nestler JE. Prevalence and characteristics of the metabolic syndrome in women with polycystic ovary syndrome. J Clin Endocrinol Metab 2005; 90: 1929-35. [CrossRef]

24. Ehrmann DA, Barnes RB, Rosenfield RL, Cavaghan MK, Imperial J. Prevalence of impaired glucose tolerance and diabetes in women with polycystic ovary syndrome. Diabetes Care 1999; 22: 141-6. [CrossRef]

25. Vgontzas AN, Legro RS, Bixler EO, Grayev A, Kales A, Chrousos GP. Polycystic ovary syndrome is associated with obstructive sleep apnea and day time sleepiness: role of insulin resistance. J Clin Endocrinol Metab 2001; 86: 517-20. [CrossRef]

26. Hardiman P, Pillay OS, Atiomo W. Polycystic ovary syndrome and endometrial carcinoma. Lancet 2003; 361: 1810-2. [CrossRef]

27. Legro RS. Polycystic ovary syndrome and cardiovascular disease: A premature association. Endocr Rev 2003; 24: 302-12. [CrossRef]

28. Krentz AJ, von Muhlen D, Barrett-Connor E. Searching for polycystic ovary syndrome in postmenopausal women: evidence of a dose-effect association with prevalent cardiovascular disease. Menopause 2007; 14: 284-92. [CrossRef]

29. Shaw LJ, Bairey Merz CN, Azziz R, Stanczyk FZ, Sopko G, Braunstein $\mathrm{GD}$, et al. Postmenopausal women with a history of irregular men- ses and elevated androgen measurements at high risk for worsening cardiovascular event-free survival: results from the National Institutes of Health-National Heart, Lung, and Blood Institute sponsored Women's Ischemia Syndrome Evaluation. J Clin Endocrinol Metab 2008; 93: 1276-84. [CrossRef]

30. Holte J, Bergh T, Berne C, Lithell H. Serum lipoprotein lipid profile in women with the polycystic ovary syndrome: relation to anthropometric, endocrine and metabolic variables. Clin Endocrinol (Oxf) 1994; 41: 463-71. [CrossRef]

31. Robinson S, Henderson AD, Gelding SV, Kiddy D, Niththyananthan $\mathrm{R}$, Bush A, et al. Dyslipidaemia is associated with insulin resistance in women with polycystic ovaries. Clin Endocrinol (Oxf) 1996; 44: 277-84. [CrossRef]

32. Talbott E, Guzick D, Clerici A, Berga S, Detre K, Weimer K, et al. Coronary heart disease risk factors in women with polycystic ovary syndrome. Arterioscler Thromb Vasc Biol 1995; 15: 821-6. [CrossRef]

33. Zouboulis CC, Chen WC, Thornton MJ, Qin K, Rosenfield R. Sexual hormones in human skin. Horm Metab Res 2007; 39: 85-95. [CrossRef]

34. Mowszowicz I, Wright F, Vincens M, Rigaud C, Nahoul K, Mavier P, et al. Androgen metabolism in hirsute patients treated with cyproterone acetate. J Steroid Biochem 1984; 20: 757-61. [CrossRef]

35. Witchel SF. Hirsutism and polycystic ovary syndrome In: Lifshitz F, ed. Pediatric Endocrinology. New York: Informa Healthcare USA Inc; 2007. p.325-48.

36. Cusan L, Dupont A, Gomez JL, Tremblay RR, Labrie F. Comparison of flutamide and spironolactone in the treatment of hirsutism: a randomized controlled trial. Fertil Steril 1994; 61: 281-7.

37. Attia GR, Rainey WE, Carr BR. Metformin directly inhibits androgen production in human thecal cells. Fertil Steril 2001; 76: 517-24. [CrossRef]

38. Yildiz BO. Recent advances in the treatment of polycystic ovary syndrome. Expert Opin Investig Drugs 2004; 13: 1295-305. [CrossRef]

39. Morin-Papunen LC, Vauhkonen I, Koivunen RM, Ruokonen A, Martikainen HK, Tapanainen JS. Endocrine and metabolic effects of metformin versus ethinyl estradiol-cyproterone acetate in obese women with polycystic ovary syndrome: a randomized study. J Clin Endocrinol Metab 2000; 85: 3161-8. [CrossRef]

40. Mastorakos G, Koliopoulos C, Creatsas G. Androgen and lipid profiles in adolescents with polycystic ovary syndrome whowere treated with two forms of combined oral contraceptives. Fertil Steril 2002; 77: 919-27. [CrossRef]

41. Mastorakos G, Koliopoulos C, Deligeoroglou E, DiamantiKandarakis E, Creatsas G. Effects of two forms of combined oral contraceptives on carbonhydrate metabolism in adolescents with polycystic ovary syndrome. Fertil Steril 2006; 85: 420-7. [CrossRef]

42. Orbetsova M, Kamenov Z, Kolarov G, Zakharieva S, Khristov V, Atanasova I, et al. Effect of 6-month treatment with oral antiandrogen alone and in combination with insulin sensitizers on body composition, hormonal and metabolic parameters in women with polycystic ovary syndrome (PCOS) in order to determine therapeutic strategy. Akush Ginekol (Sofiia) 2006; 45: 16-28.

43. Du Q, Yang S, Wang YJ, Wu B, Zhao YY, Fan B. Effects of thiazolidinediones on polycystic ovary syndrome: a meta-analysis of randomized placebo-controlled trials. Adv Ther 2012; 29: 763-74. [CrossRef]

44. Gode F, Karagoz C, Posaci C, Saatli B, Uysal D, Secil M, et al. Alteration of cardiovascular risk parameters in women with polycystic ovary syndrome who were prescribed to ethinylestradiol-cyproterone acetate. Arch Gynecol Obstet 2011; 284: 923-9. [CrossRef] 
45. Teede HJ, Meyer C, Hutchison SK, Zoungas S, McGrath BP, Moran LJ. Endothelial function and insulin resistance in polycystic ovary syndrome: the effects of medical therapy. Fertil Steril 2010; 93: 184-91. [CrossRef]

46. Ozkaya M, Cakal E, Ustun Y, Engin-Ustun Y. Effect of metformin on serum visfatin levels in patients with polycystic ovary syndrome. Fertil Steril 2010; 93: 880-4. [CrossRef]

47. Kriplani A, Periyasamy AJ, Agarwal N, Kulshrestha V, Kumar A, Ammini AC. Effect of oral contraceptive containing ethinyl estradiol combined with drospirenone vs. desogestrel on clinical and biochemical parameters in patients with polycystic ovary syndrome. Contraception 2010; 82: 139-46. [CrossRef]

48. Pehlivanov B, Mitkov M. Efficacy of an oral contraceptive containing drospirenone in the treatment of women with polycystic ovary syndrome. Eur J Contracept Reprod Health Care 2007; 12: 30-5. [CrossRef]
49. Aydin K, Cinar N, Aksoy DY, Bozdag G, Yildiz BO. Body composition in lean women with polycystic ovary syndrome: effect of ethinyl estradiol and drospirenone combination. Contraception 2013; 87: 358-62. [CrossRef]

50. Nakhjavani M, Hamidi S, Esteghamati A, Abbasi M, NosratianJahromi S, Pasalar P. Short term effects of spironolactone on blood lipid profile: a 3-month study on a cohort of young women with hirsutism. Br J Clin Pharmacol 2009; 68: 634-7. [CrossRef]

51. Ganie MA, Khurana ML, Eunice M, Gupta N, Gulati M, Dwivedi SN, et al. Comparison of efficacy of spironolactone with metformin in the management of polycystic ovary syndrome: an open-labeled study. J Clin Endocrinol Metab 2004; 89: 2756-62. [CrossRef]

52. Harrison CL, Lombard CB, Moran LJ, Teede HJ. Exercise therapy in polycystic ovary syndrome: a systematic review. Hum Reprod Update 2011; 17: 171-83. [CrossRef]

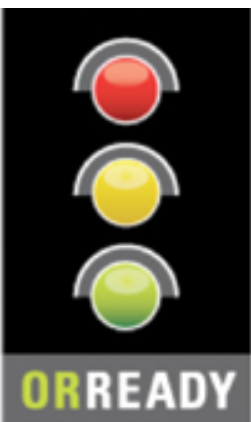

We are ORReady and support operating room safety to improve patient outcome.
ORReady is a worldwide, multi-Specialty initiative to encourage steps that are known to improve surgical outcomes and save lives.

If the suggested guidelines, which include Check Lists, Time Outs and Warm Ups are followed routinely, we estimate that Six Million patients around the world could have better outcomes.

Find out how your department and hospital can be ORReady and improve outcomes at http://www.sls.org/outcome 